\title{
Elmira Resić
}

\section{NERESTRIKTIVNA RELATIVNA REČENICA KAO PARENTETIK}

$\mathrm{U}$ ovome ćemo radu nastojati opisati umetnute nerestriktivne relativne rečenice kao tipične parentetičke strukture. Opis će podrazumijevati njihovu sintaksičku i semantičku interpretaciju, ali i naznake o njihovoj pragmatičkoj ulozi i zasnivat će se na analizi primjera pronađenih u korpusu tekstova koji pripadaju različitim stilovima bosanskoga jezika. Rad je podijeljen u tri dijela. U prvom ćemo dijelu definirati parentetike i dati pregled dosadašnjih pristupa u analiziranju te pojave. U drugome dijelu rada fokusirat ćemo se na definiranje i analizu umetnutih nerestriktivnih relativnih rečenica, a u trećem će se dijelu izdvojiti najznačajnija zapažanja.

\section{O umetnutim strukturama}

Umetnute su strukture vrlo kompleksna i za naučnu analizu zanimljiva pojava. Te su strukture zauzele značajno mjesto u svjetskoj lingvistici (Urmson 1952, Quirk 1985, Espinal 1991, Potts 2005, Burton-Roberts 2006, Kaltenbock 2007, Steinbach 2007, De Vries 2007, Dehe, Kavalova 2007, Dehe 2009, Griffiths 2013, Kluck 2015), a nisu ostale u potpunosti zanemarene ni u radovima južnoslavenskih lingvista (Maretić 1963, Brabec i dr. 1970, Stevanović 1979, Kovačević 1988, Barić i dr. 1997, Mihaljević 2013, Palić 2015). Ipak, u srbistici, kroatistici i bosnistici ovom se fenomenu najčešće pristupalo sintaksički s nastojanjem da se umetnute strukture pozicioniraju na sintagmatskoj razini. Naravno, i južnoslavenski lingvisti uočavaju njihove semantičke i pragmatičke naročitosti, ali 
se njima ne bave detaljno te takve osobine umetnutih struktura ostaju na nivou prepoznavanja. Ipak, odmak od takvog, čisto formalnog i strukturnog, pristupa napravio je Palić (2015) baveći se umetnutim klauzama s konjunktorima $a$ i $i$. Iako je i kod Palića akcent stavljen na sintaksičko određenje umetnutih klauza, autor govori i o semantičkoj dimenziji i pragmatičkim razlozima za njihovo formiranje.

Prije nego pređemo na analizu umetnutih struktura, nužno je definirati ih i osvrnuti se na teorijske zaključke do kojih se do sada došlo. Umetnute su strukture (umeci, parentetici ${ }^{1}$, interpolirane strukture, suplementi, disjunkti, tetici) takve strukture koje se u pisanju prepoznaju po tome što su različitim pravopisnim znacima (zarezima, crtama, zagradama) odvojene od ostatka izraza, a u govoru po pauzama i promijenjenoj intonaciji. Prvo pitanje koje se pojavilo u vezi s interpretiranjem parentetika bilo je pitanje pristupa - da li je takve strukture potrebno i moguće interpretirati sintaksički, ili je nužno izaći iz okvira sintakse i u interpretaciju obavezno uključiti znanja iz drugih lingvističkih disciplina. Uočeno je da te strukture izlaze izvan okvira hijerarhijskih zakonitosti koje nameće gramatika rečenice. Kako navodi Burton-Roberts (2006: 179-182), na složenost fenomena parentetika ukazala je Espinal (1991: 726-762) u studiji u kojoj analizira sve one izraze koji se prepoznaju kao umeci u nekoj strukturi (autorica koristi naziv disjunct constituents). Pokušavajući riješiti problematičan odnos linearnosti i hijerarhije kod umetnutih struktura, Espinal (1991: 727) navodi kako parentetici nisu sami po sebi parentetici, nego im takav status daje činjenica da ih doživljavamo kao nezavisne konstrukcije unutar nekih drugih konstrukcija, te da one nose manje gramatičkih informacija od okruženja u koje su umetnute. Espinal (1991: 729-735) uspostavlja nekoliko kriterija koji potvrđuju sintaksičku izoliranost tih struktura. Također, Espinal prepoznaje i njihove semantičke i pragmatičke osobine i smatra da je takve izraze najbolje analizirati na nivou koji nadilazi sintaksu i interpretirati ih kao trenutak govora. ${ }^{2}$

Termin parentetici najčešće se koristi u svjetskoj lingvistici i njime su obuhvaćene najrazličitije vrste umetnutih struktura, pa će se isti termin koristiti u nastavku i u ovome radu.

2 Opisivanje parentetika sa stajališta sintaksičke integracije ili sintaksičke izoliranosti podrazumijeva uspostavljanje vrlo oštrih granica između gramatike rečenice (engl. sentence grammar) i gramatike diskursa (engl. discourse grammar), a upravo su parentetici strukture koje govore da ova dva pristupa ne mogu biti oštro razgraničena. 
Od sintaksičkog kriterija polazi i Burton-Roberts (2006: 179) kada parentetike definira kao strukture koje su udomljene ${ }^{3}$ u neku drugu strukturu, ali toj strukturi ne doprinose. Sintaksička je neovisnost parentetika, kako navodi BurtonRoberts, posebno primjetna kod apozitiva jer oni imaju istu sintaksičku funkci$\mathrm{ju}^{4}$ kao i elementi prema kojima su apozitivi.

Parentetici su, kao sintaksički izolirane jedinice, predstavljeni i u radovima drugih lingvista (Haegeman 1988, Peterson 1999)5, a javljaju se i oni lingvisti koji pokušavaju pomiriti suprotnosti između linearne uključenosti i hijerarhijske neuključenosti uvodeći nove pristupe koji podrazumijevaju postojanje nekoga izraza višega nivoa, čiji su strukturni elementi naporedo i glavni izraz i parentetik (Emonds 1979), postojanje nivoa logičke forme koja objedinjuje i glavni izraz i parentetik (Safir 1986) te razvijajući teoriju o „pravilima pomjeranja“ (engl. movement rules) (McCawley 1982).

Palić (2015), baveći se umetnutim klauzama s konjunktorima $a$ i $i$, govori o strukturnoj povezanosti tih parentetika s domaćinskom klauzom. Strukturna je povezanost, kako autor zaključuje na osnovu primjera, neosporna kod onih parentetika koji u sebi sadrže anafore, a domaćinske strukture njihove antecedente. Slabiji je stepen sintaksičke integracije, kako navodi Palić (2015: 114), kod slobodnih umetnutih klauza koje referiraju na cjelinu sadržaja domaćinske klauze. Pored sintaksičke integracije, Palić analizira i narav samoga odnosa između domaćinske strukture i umetnutih klauza s konjunktorima $a$ i $i$ potvrđujući da se radi o neprototipičnoj koordinaciji.

Iako je pitanje sintaksičke uključenosti / neuključenosti parentetika u domaćinsku strukturu zauzelo najviše mjesta u studijama koje se bave tom pojavom, mnogi autori zagovaraju postavljanje semantičkih i pragmatičkih kriterija na prvo mjesto. Naime bez obzira na to da li je parentetik konstituent na sintagmatskom nivou ili je sintaksički izolirana struktura, njegova pojava u linearnom nizu mora imati određene efekte na cijelu strukturu. Ti se efekti prepoznaju

\footnotetext{
3 Termin udomljavanje u vezi je s nazivom koji se u svjetskoj lingvistici koristi za onu strukturu u kojoj se parentetik linearno ostvaruje (engl. host structure). Mi ćemo, za potrebe ovoga rada, preuzeti terminologiju koju Palić (2015) nudi - domaćinska struktura i parentetik (umetak).

${ }_{4}$ Činjenica da parentetik ima istu funkciju kao i neki element u strukturi u kojoj je udomljen jasan je pokazatelj da oba elementa ne pripadaju istoj sintaksičkoj strukturi, jer, kako ističe Espinal (1991: 730), nije moguće „naći unutar jedne rečenice dva subjekta ili dva direktna objekta uz isti predikat“.

5 Prema Dehe, Nicole; Kavalova, Yordanka (ur.). 2007. Parentheticals. John Benjamins Publishing Company. Amsterdam - Philadelphia.
} 
na izvangramatičkom nivou, oni su semantički, pragmatički, diskursni, i zbog toga je pojava parentetika važna za razumijevanje cijeloga iskaza. Sperber i Wilson (1986: 229), razvijajući teoriju relevantnosti, navode kako svaki iskaz ima dvostruku sposobnost - može biti upotrijebljen deskriptivno ili interpretativno. Interpretativnu funkciju autori pripisuju određenim vrstama parentetika budući da oni doprinose interpretaciji strukture u kojoj su ostvareni. Posmatrani kroz teoriju relevantnosti, parentetici su strukture kod kojih u prvi plan dolazi njihova pragmatička ${ }^{6}$ funkcija, a ne njihov sintaksički status.

Umetnute strukture analizirane su i kao konvencionalne implikature. Naime, Potts (2005) govori o suplementima ${ }^{7}$ i ekspresivima kao strukturama koje posjeduju osobine konvencionalnih implikatura. Kako navodi Potts (2005: 33), informacije koje suplementi nose nove su u odnosu na kontekst; kada bi bile sadržane u pozadinskom kontekstu, ${ }^{8}$ ne bi bile ni potrebne jer bi vodile redundanciji. Naime, sadržaj iskazan suplementom nije u prvome planu, on je defokusiran $\mathrm{u}$ odnosu na sadržaj konteksta u kojem se ostvaruje, ali je po svome opsegu širi. Taj je sadržaj, kako primjećuje Potts (2005: 44), komentar koji se odnosi ili na neki dio glavnoga konteksta ili na okolnosti samoga iskaza. Također, neovisnost suplementa u odnosu na okolni kontekst manifestira se i prilikom analiziranja uvjeta istinosti. Naime, istinitost ili neistinitost okolnog konteksta ne zavisi od istinitosti suplementa, a isto vrijedi i obrnuto (Potts 2005: 49).

Utjecaj parentetika na uvjete istinitosti domaćinske strukture interpretirala je na drugačiji način Blakemore (2002). Blakemore, zapravo, postavlja pitanje samoga značenja termina uvjeti istinitosti (engl. truth conditions) i navodi kako ga možemo interpretirati na dva načina. Prvi je način onaj koji predlaže Potts, a koji podrazumijeva da su uvjeti istinitosti determinirani značenjem upotrijebljenih riječi. S druge strane, uvjeti istinitosti ne moraju biti u vezi sa značenjem upotrijebljenih riječi, već mogu biti povezani sa širom misli, širim kontekstom koji određena struktura aktualizira. U tom slučaju, parentetik može utjecati na

\footnotetext{
O pragmatičkim svojstvima parentetika više u Palić 2015: 138-139.

Potts termin suplementi koristi za imenovanje struktura koje su najčešće ostvarene između zareza i koje su nezavisne od svoga konteksta (parentetici i apozitivi).

8 Uspostavljajući razliku između konverzacijskih implikatura i konvencionalnih implikatura, Potts govori o tome kako je značenje potonjih sadržano u samome značenju leksema kojima su izražene i da to značenje nije prisutno kao zajedničko govorniku i slušaocu, dakle nije sadržano u širem kontekstu (engl. antibackgrounding).
} 
uvjete istinitosti domaćinske strukture, ali na nivou pragmatičke interpretacije (Blakemore 2002: 16).

Na pragmatičku funkciju parentetika vrlo je rano ukazao Quirk (1985) nazivajući ih klauzama komentara (engl. comment clause). Za njega su parentetičke strukture rečenični disjunkti koje karakterizira naročita intonacija, neintegriranost u širi kontekst, a osnovna im je funkcija iskazivanje govornikovih uvjerenja o rečenome ili komentara na sami sadržaj. Quirk, dakle, i prilikom imenovanja pojave postavlja funkcionalni kriterij prije formalnog i izvodi nekoliko tipova ovih struktura.

Metodološkim problemima (miješanje formalnog i funkcionalnog kriterija, nedosljednost u njihovoj primjeni, davanje prednosti jednome ili drugome) prilikom analize različitih vrsta parentetika bavio se Kaltenbock (2007). Kaltenbock (2007: 33) primjećuje kako je analiza parentetika u radovima mnogih autora nepotpuna zato što su zanemareni ili isključeni bilo formalni bilo funkcionalni aspekti njihova postojanja, pa u većini radova o parenteticima susrećemo „funkcionalnu karakterizaciju neke forme“. Osim toga Kaltenbock ukazuje da manjkavost onih pristupa koji parentetike određuju primarno u odnosu na domaćinsku strukturu i na ono što ovim jedinicama u toj strukturi nedostaje (integriranost $u$ domaćinsku strukturu, fonološko jedinstvo). Pokušavajući sistematizirati parentetičke strukture i uočavajući veću postojanost formalnog nego funkcionalnog kriterija, Kaltenbock uspostavlja tri kriterija za njihovu analizu - forma, nedostatak sintaksičke veze s domaćinskom strukturom i pozicijska fleksibilnost. ${ }^{9}$ Primjenom navedenih kriterija autor govori o vrstama klauzalnih parentetika.

Kaltenbock, Heine i Kuteva (2011) uspostavljaju termin gramatika tetika ${ }^{10}$ koja, zajedno s gramatikom rečenice, učestvuje u gramatici diskursa. U njihovoj interpretaciji tetici samostalno formiraju iskaz te imaju svoju posebnu, unutrašnju gramatiku i ona ne zavisi od strukturnih pravila koja nameće gramatika rečenice, ali zajedno s gramatikom rečenice učestvuje u organiziranju diskursa (Kaltenbock, Heine i Kuteva 2011: 873). Također, u govornom su diskursu tetič-

\footnotetext{
9 Ova tri kriterija autor primjenjuje na klauzalne parentetike zaključujući kako su oni ipak sintaksički izolirani u odnosu na domaćinsku strukturu, dok je kod neklauzalnih ponekad primijetna čvršća povezanost s domaćinskom strukturom.

10 Autori se opredjeljuju za termin tetici koji je značenjski nešto širi od termina parentetici (pokriva i one strukture koje se ostvaruju i inicijalno i finalno).
} 
ke jedinice komunikativno značajnije za govornike te im se stoga ne bi trebala pripisivati sekundarna uloga.

$\mathrm{Na}$ osnovu prethodno rečenog jasno je da se o parenteticima, sintaksički gledano, može govoriti kao o integriranim ili neintegriranim strukturama. Svakako, integracija može imati i šire značenje i uključivati diskurs kao kontekst koji objedinjuje i domaćinsku strukturu i parentetik pa se onda parentetik ne posmatra u odnosu na neposrednu strukturu u kojoj je linearno ostvaren, već u odnosu na situacijski kontekst koji, zajedno s domaćinskom strukturom, proizvodi. Naravno, postoje nezaobilazni argumenti koji daju legitimitet i jednome i drugome pristupu te se o parenteticima ne smije govoriti isključivo kao o apsolutno izoliranim ili apsolutno integriranim jedinicama. Osim sintaksičkog odnosa prema ostatku strukture parentetici su zanimljivi i zbog svoje unutrašnje sintakse. Vrlo je jasno da je, analizirajući njihovu unutrašnju strukturu, riječ o izuzetno složenoj i heterogenoj pojavi. Ta se složenost $\mathrm{i}$ heterogenost ogleda u postojanju velikog broja najrazličitijih struktura koje se ostvaruju kao parentetici.

Najjednostavnija podjela parentetika razvrstava ih u dvije velike grupe: klauzalne (nerestriktivna relativna klauza, različite vrste adverbijalnih klauza, klauza komentara, eliptična klauza) i neklauzalne parentetike (supstantivne sintagme, rečenični adverbijali, jednočlani izrazi, diskursni markeri, ehopitanje). Kod takve je podjele osnovni kriterij unutrašnja forma parentetika, odnosno da li se radi o rečenici ili manjoj sintaksičkoj jedinici koja nema obilježje predikativnosti. Zanimljivo je kako su pojedini glagoli (vjerujem, znam, pretpostavljam, osjećam) koji obrazuju klauze komentara interpretirani kao jedinice kod kojih je parentetička funkcija dominantna kada god su upotrijebljeni u prvome licu prezenta. ${ }^{11}$ Urmson (1952: 495) navodi kako se ovi glagoli u engleskome jeziku ponašaju kao jedinice kod kojih u prvi plan ne dolazi deskriptivna funkcija (sposobnost da označe radnju ili stanje), već oni figuriraju kao signali kako govornik treba interpretirati kontekst. Još je jedna vrsta glagola upotrijebljenih parentetički zanimljiva s aspekta njihova odnosa prema ostatku strukture. Riječ je, naime, o glagolima govorenja koji se pojavljuju u neupravnome govoru. Mihaljević (2013) parentetičke strukture s ovim glagolima analizira kao strukture koje sintaksički nisu neovisne o kontekstu u kojem se ostvaruju i navodi da je odnos prema tom kontekstu uvjetovan njihovom unutrašnjom strukturom. Zanim-

O tome više u Urmson 1952. 
ljiv je stav koji iznosi De Vries (De Vries 2007) o parentetičkim strukturama s glagolima govorenja usmjerenim prema subjektu. ${ }^{12}$ De Vries (2007: 204) tvrdi kako te strukture, ukoliko se nađu na kraju domaćinske strukture, uopće nisu parentetici, već da je kod njih samo subordinirana klauza u prepoziciji u odnosu na glavnu.

Osim podjele na klauzalne i neklauzalne parentetike, koja je primarno motivirana njihovom unutrašnjom formom, postoje i brojne druge podjele koje su zasnovane na kombiniranju sintaksičkih, semantičkih i pragmatičkih kriterija. Jedna od takvih parentetike dijeli u tri skupine: trenutni, konstrukcijski i formulaični (Kaltenbock, Heine i Kuteva 2011: 871). Svi se oni međusobno razlikuju po unutrašnjoj strukturi i po funkcionalnim karakteristikama, a pokrivaju sve one sintaksički različite pojave koje autori proglašavaju parenteticima. Kavalova (2007) govori o usidrenim i plutajućim parenteticima. Ta je podjela zasnovana na vezi koju parentetik ostvaruje s domaćinskom strukturom. Podjela parentetika može primarno počivati na semantičkim osnovama i takve strukture posmatrati kao nositelje različitih značenja. Grenoble (2004) govori o proceduralnim i konceptualnim parenteticima zasnivajući ovu podjelu na razlici između konceptualnog i proceduralnog značenja. ${ }^{13}$

\section{Nerestriktivna relativna rečenica kao parentetik}

U prvome je poglavlju već kazano kako postoje različite vrste parentetičkih struktura koje pokazuju određene osobine zanimljive sa sintaksičkog, semantičkog i pragmatičkog stajališta. Među ovim strukturama posebno mjesto zauzima i umetnuta nerestriktivna relativna rečenica. Prije analize u korpusu pronađenih primjera potrebno je definirati ovu vrstu rečenice i ukazati na njene osobine. Kordić (1995: 15) određuje relativnu (odnosnu) rečenicu kao zavisnu rečenicu koja uspostavlja odnos s nekom imeničkom ili upućivačkom riječju iz

\footnotetext{
12 Termine usmjeren prema subjektu (engl. subject-oriented) i usmjeren prema govorniku (engl. speakeroriented) uvela je T. Reinhart 1983. godine (Reinhart 1983: 176).

13 Jedna od prvih koja je uspostavila razliku između proceduralnog i konceptualnog značenja bila je Blakemore (1987). Naime, neke jedinice stvaraju koncepte koji učestvuju u konceptualnoj reprezentaciji i utječu na uvjete istinitosti iskaza u kojem se ostvaruju. Takve jedinice imaju konceptualno značenje. S druge strane, postoje jedinice koje ne utječu na uvjete istinitosti i koje postavljaju proceduralne okvire interpretacije. Takve jedinice imaju proceduralno značenje.
} 
glavne rečenice, a ta se relacija prepoznaje čak i onda kada je u glavnoj rečenici takva riječ ispuštena. Autorica dijeli sve relativne rečenice na restriktivne i nerestriktivne, a kao osnovnu razlikovnu osobinu između ovih dvaju tipova navodi odnos relativizatora prema svome antecedentu. Naime, restriktivna se rečenica prepoznaje po tome što sužava opseg referenta imenske riječi (ponaša se, dakle, kao odredba), a nerestriktivna ne utječe na opseg referenta i predstavlja samo njegovu dopunu (Kordić 1995: 25). Osim toga Kordić primjećuje kako se restriktivna i nerestriktivna relativna rečenica drugačije ponašaju i kada je riječ o strukturnom predstavljanju jer se kod restriktivne najprije vrši atribucija pa onda determinacija, a kod nerestriktivne najprije se vrši determinacija pa atribucija nije ni potrebna za uspostavljanje referencije. Osim termina restriktivna i nerestriktivna relativna rečenica, u literaturi se koriste i drugi nazivi koji su signali njihove različite funkcije prema glavnoj rečenici: determinativna i apozitivna rečenica, determinativna i deskriptivna rečenica, definirajuća i nedefinirajuća rečenica, integrirana i dopunska rečenica (prema Loock 2010). Upotrijebljeni nazivi ukazuju na sintaksičke i semantičke osobine navedenih relativnih rečenica. Zapravo, oni govore o položaju relativne rečenice u odnosu na glavnu i o sintaksičkoj vezi među njima, ali i o naravi referencijalne relacije koju relativne rečenice uspostavljaju sa svojim antecedentom. Tako restriktivna relativna rečenica zajedno s antecedentom uspostavlja referenciju (radi se dakle o odnosu varijantnosti), dok je nerestriktivna referencijski samostalna i donosi dodatne informacije o antecedentu. Pojavu nerestriktivne ili restriktivne relativne rečenice, kako je primijećeno u literaturi, uvjetuje i narav antecedenta. Tako antecedenti koji imaju unaprijed određenu referenciju (vlastita imena ili lične zamjenice) u pravilu uvode nerestriktivnu relativnu rečenicu, dok antecedenti koje popunjavaju opće imenice ili pojedini determinatori mogu uvesti i nerestriktivne i restriktivne relativne rečenice. ${ }^{14}$ Također, ukoliko je antecedent supstantivna sintagma koja u sebi sadrži neki kvantifikator, iza nje bi se trebala javiti restriktivna relativna klauza. ${ }^{15}$ Razlike između restriktivne i nerestrik-

\footnotetext{
Više u Kordić 1995.
}

15 Iako se smatra da nominalne fraze s kvantifikatorima ne uvode nerestriktivne relativne rečenice, Del Gobbo (2007) vjeruje kako i u takvim slučajevima možemo imati nerestriktivnu relativnu rečenicu, ali se ona tada mora pojaviti u finalnoj poziciji (poslije glavne rečenice) ili zamjenica koja uvodi nerestriktivnu relativnu rečenicu mora imati generičko značenje. 
tivne relativne rečenice posmatraju se i kroz odnos komplementa i adjunkta. ${ }^{16}$ Jackendoff (1977) navodi kako se nerestriktivne relativne rečenice ponašaju više kao adjunkti, a restriktivne kao komplementi. U engleskome se jeziku razlika između restriktivnih i nerestriktivnih relativnih rečenica uspostavlja i prema relativizatoru koji ih uvodi. Naime, primijećeno je kako se nerestriktivne relativne rečenice ne uvode relativizatorom that (koji) i da su one, gotovo uvijek, uvedene wh-relativizatorima. Osim što se relativna rečenica može odnositi na imeničku ili neku upućivačku riječ iz glavne rečenice, Loock (2010: 35) navodi kako nerestriktivna (apozitivna) relativna rečenica u svome antecedentu može imati verbalnu, adverbijalnu, adjektivnu sintagmu pa čak i cijelu rečenicu kao antecedent. ${ }^{17} \mathrm{I}$ tu se ona razlikuje od restriktivne, kojoj je antecedent samo supstantivna sintagma. Nerestriktivna i restriktivna relativna rečenica razlikuju se i po načinu bilježenja. Upravo je nerestriktivna relativna rečenica ona koja se ostvaruje parentetički, te se ona u pisanome diskursu najčeće odvaja zarezima (ili nekim drugim interpunkcijskim znakovima). Budući da se restriktivna relativna rečenica nikad ne odvaja zarezima, možemo kazati kako zarezi funkcioniraju kao signali nerestriktivnosti. Naravno, postojanje zareza nije apsolutni pokazatelj nerestriktivnosti, ali govori o tome kako struktura odvojena zarezima nema isti status (sintaksički, semantički, prozodijski) kao ostatak iskaza.

Zajednička je odlika i restriktivnih i nerestriktivnih relativnih rečenica njihova postpozicija u odnosu na antecedent. Ta se postpozicija ne ostvaruje kod onih relativnih rečenica koje Kordić (1995: 212) imenuje kao slobodne, budući da u njima antecedent formalno nije ni ostvaren. Također, još je jedna zajednička odlika obiju vrsta relativnih rečenica. Riječ je o njihovom kontaktnom položaju u odnosu na antecedent. Kontaktni je položaj ujedno i najtipičniji, ali se u literaturi (Tabakowska 1985, Browne 1986) svakako govori i o ekstraponiranim relativnim rečenicama. Takve se rečenice formalno ostvaruju bliže kraju rečenice i mnogo su rjeđe od onih kod kojih antecedent prethodi relativizatoru. U ovome radu termin umetnuta nerestriktivna relativna rečenica odnosi se na sve one rečenice koje se ostvaruju unutar jedne rečenice ili između dviju klauza složene

\footnotetext{
16 O interpretiranju relativne rečenice kao komplementa glave nominalne fraze koja je antecedent ili adjunkta prema cijeloj nominalnoj frazi pogledati više u Alexiadou i dr. 2000.

17 Silić i Pranjković (2005: 329) zavisnosložene rečenice u kojima se zavisna klauza odnosi na cijelu osnovnu klauzu nazivaju raščlanjenim rečenicama.
} 
rečenice, a uspostavljaju relaciju ili prema nominalnoj frazi u domaćinskoj rečenici ili prema cijelom sadržaju domaćinske rečenice.

Budući da se nerestriktivna relativna rečenica uvijek ostvaruje kao parentetik, analiza te vrste rečenice trebala bi dati odgovore na najvažnija pitanja koja se u vezi s parenteticima aktueliziraju - da li je riječ o integriranom ili izoliranom sintaksičkom elementu, kakva je narav odnosa između parentetika i domaćinske strukture, da li i na koji način parentetik utječe na interpretaciju domaćinske strukture. Kako bismo pokušali dati odgovor na ova pitanja, navest ćemo nekoliko primjera:

(1) Možemo li mi, ti i ja, koji imamo različita tijela a duše iste, sada razmišljati kako vijekovi prolaze... (FSP)

(2) Umjesto njega, neki novi, koji ga očigledno nije poznavao i učio latinski ko zna gdje, ako ga je uopće znao, izgurao ga je... (HIP)

(3) ...onaj leptir, koji je možda s njom došao i tražio plamen, izgorio je... (BAM)

(4) Jedan od osmorice iz dobrotvornog društva, koji mu je ponio vode, pretr$\mathrm{nu}$, zastade, boca mu gotovo ispade iz ruke.

(5) To malo siroče, što je ostalo bez roditelja, gledao je svak milo i javio joj se milije... (BAM)

(6) Ona lijepa zgrada, što ju je njena mašta sačinila od sanja i ideala od želja i težnja, ležala je porušena. (BAM)

(7) Kapci žene, što ju je okrutna životna stvarnost prerano učinila staricom, zadrhtaše... (BNLJ)

U primjerima od (1) do (7) nerestriktivna relativna rečenica ostvaruje se unutar linearnog ustrojstva jedne rečenice. Relativizatori koji uvode nerestriktivne rečenice su zamjenica koji i veznik što, a sve se navedene nerestriktivne relativne rečenice odnose na neku imeničku riječ iz domaćinske strukture. Da li su umetnute nerestriktivne relativne rečenice $u$ ovim primjerima sintaksički izolirane jedinice u odnosu na domaćinsku rečenicu ili su one, ipak, njeni konstituenti. Sintaksička izoliranost podrazumijevala bi da ne postoji nikakva sintaksička veza između domaćinske strukture i parentetika. Ukoliko pogledamo primjere (6) i (7), vidjet ćemo da parentetičke strukture sadrže anafore (u oba primjera 
zamjenica u enklitičkom obliku $j u$ ) koje uspostavljaju vezu s antecedentima iz domaćinske rečenice (imenica zgrada u primjeru (6) i imenica žena u primjeru (7)). Postojanje anaforičke relacije između parentetika i domaćinske strukture znak je njihove sintaksičke povezanosti. Naravno, pojava anafore u parentetičkoj strukturi rezultat je funkcionalne ograničenosti nepromjenjivog relativizatora što da sintaksički zastupa antecedent te ovu funkciju na sebe preuzima zamjenica. U primjeru (5) zamjenica s anaforičkom funkcijom ne pojavljuje se zato što bi antecedent $u$ relativnoj rečenici imao funkciju subjekta, a o izostavljanju te zamjenice u funkciji subjekta i direktnog objekta govorili su Keenan i Comrie (1977). Naime, spomenuti autori navode kako relativizatori imaju sposobnost čuvanja sintaksičko-semantičke funkcije koju je imao antecedent, a da su pojedine funkcije pristupačnije i samome antecedentu i relativizatoru. Po kriteriju pristupačnosti, na prvome mjestu dolazi subjekt, te je relativizatoru ova funkcija dostupna i ne zahtijeva uvođenje zamjenice kao sredstva koje će je precizirati. U primjerima od (1) do (4) nerestriktivna relativna rečenica uvedena je relativizatorom koji. Budući da je riječ o promjenjivom relativizatoru koji sintaksički zastupa svoj antecedent, ovaj relativizator uvijek kongruira sa svojim antecedentom u rodu i broju. Kongruencija koja se uspostavlja između jednog člana parentetika i jednog člana domaćinske strukture pokazatelj je da među njima ipak postoji sintaksička povezanost, odnosno da antecedent iz domaćinske strukture nameće sintaksička ograničenja za pojavljivanje relativizatora.

Povezanost domaćinske strukture i parentetika koja se manifestira kroz ograničenja koja antecedent postavlja pred parentetičku strukturu posebno je izražena kada se na mjestu antecedenta nađu vlastita imena, lične zamjenice ili determinatori. U ovim slučajevima narav antecedenta uvjetuje tumačenje parentetičke relativne rečenice kao restriktivne ili nerestriktivne:

(8) Poslije dženaze, našao sam se na istom putu sa Alijom, koji je neka vrsta dobrog duha Grada, kojeg dobronamjerni smatraju osobenjakom... (HIP)

(9) Jedno jutro otišla Asim-efendiji, koji je upravljao njezinim imetkom, i zamolila ga da joj dadne nešto novaca. (BAM)

(10) Bože, koji sve vidiš i čuješ, Bože veliki, koji si Svemoćan, Bože, čija je milost neizmjerna, pogledaj... (BAM) 
(11) Kako je već običaj, svi su putnici stajali na nogama; jedni, koji putuju dalje, gledali su grad i okolicu kojom je voz jurio... (BAM)

(12) Posmatrajući pažljivo sve detalje svog lica, što su mu davali prijatan $i$ istovremeno snažan izraz, Nenad odluči... (FSP)

Kada se u ulozi antecedenta nađe vlastito ime, relativna se rečenica definira kao nerestriktivna. Određenje relativne rečenice kao nerestriktivne determinirano je semantičkom osobinom vlastite imenice da imenuje pojave u vanjezičkoj stvarnosti i samostalno uspostavlja referenciju. U primjerima (8), (9) i (10) antecedenti su vlastite imenice (Alija, Asim-efendija, Bog) s unaprijed određenom referencijom te se relativna rečenica pojavljuje kao dodatna obavijest, a ne kao odredba antecedenta.

U primjeru (11) nerestriktivna relativna rečenica uvedena je preko antecedenta jedni. Riječ je o supstantiviziranom determinatoru jedan koji preuzima značenje cijele sintagme koju zastupa (jedni putnici $>$ jedni). Budući da se determinatori $\mathrm{u}$ antecedentu ponašaju kao signali za interpretiranje relativne rečenice, potrebno je kazati kako se ponaša determinator jedan (jedni) u primjeru (11). Kada bi se ostvarivao uz imenicu putnici (koja bi bila glava sintagme), determinator jedni ukazivao bi na način ostvarivanja referencije, a glava sintagme na sami pojam referencije. S obzirom na to da se cijela imenska sintagma svodi na determinator, jedni prestaje funkcionirati kao determinator i preuzima sintaksičku funkciju cijele sintagme. Ipak, pojava nerestriktivne relativne rečenice nakon antecedenta jedni pokazatelj je kako je ovaj antecedent zadržao sadržaj neodređenog determinatora jedan. Naime, u literaturi je već ukazano na vezu između pojave neodređenog determinatora jedan $\mathrm{u}$ funkciji antecedenta i nerestriktivne relativne rečenice. Premda neodređeni determinator jedan ne može precizirati referenta, on ga ipak može izdvojiti i na taj ga način specificirati, pri čemu je riječ o neodređenoj specifičnoj determinaciji. Ukoliko pogledamo primjer (11), vidjet ćemo da se antecedent jedni ponaša istovjetno kao determinator jedan budući da iz poznatog skupa referenata (svi putnici) izdvaja individualizirani podskup.

Primjer (12) pokazuje kako prisustvo prisvojne zamjenice svoj u antecedentu utječe na interpretiranje relativne rečenice. Zamjenica svoj referira na subjekt u rečenici (koji je ekspliciran i poznat) te antecedent koji sadrži ovu zamjenicu 
biva jasno određen svojom pripadnošću tom subjektu. Budući da je određen, antecedent svoju referenciju ostvaruje samostalno, a relativna rečenica koja se uz njega pojavljuje donosi dodatnu obavijest. O sintaksičkoj vezi između domaćinske rečenice i relativne rečenice kao parentetika svjedoči i anaforička relacija koja se ostvaruje između antecedenta (svog lica) i zamjenice $m u$.

Prisustvo ili odsustvo kvantifikatora u antecedentu također je signal za interpretiranje relativne rečenice kao restriktivne ili kao nerestriktivne. Većina autora navodi kako kvantifikatori u antecedentu utječu na restriktivnost relativne rečenice budući da se relativna rečenica u njima pojavljuje kao određujući podskup skupa referenata koji antecedent označava. ${ }^{18}$ Arnold (2004) ukazuje na mogućnost pojave nerestriktivne relativne rečenice nakon antecedenta koji sadrži kvantifikatore every, no (svaki, nijedan) te zaključuje kako nerestriktivne relativne rečenice mogu istovremeno biti semantički nezavisne strukture, ali zadržavati osobine sintaksički uključenih struktura. Pogledajmo sljedeće primjere:

(13) Svi ovi, kojima je narod izvojevao pobjedu, nestali su... (BAM)

(14) Obustavljeni su svi listovi, koji su bili poznati kao mladoturski, i zaplijenjene mnoge knjige. (BAM)

(15) Zašto bi se mučili ovdje gdje se ne dobiju svi oni lijekovi koji se propišu. (BAM)

(16) Svi oni koji dijele pravdu i istinu znaju da sam ovdje i znaju šta sam rekao. (INU)

Antecedenti u navedenim primjerima sadrže kvantifikator svi. Radi se o općem kvantifikatoru koji najčešće uvodi restriktivnu rečenicu budući da restriktivna rečenica u tom slučaju daje obavijest o podskupu referenata koji obuhvata imenički pojam označen antecedentom. Ukoliko pogledamo navedene primjere, vidjet ćemo da se primjeri (13) i (14) formalno razlikuju od primjera (15) i (16) jer se u njima pojavljuje zarez kao znak nerestriktivnosti relativne rečenice. Postavlja se pitanje da li je, zaista, relativne rečenice u primjerima (13) i (14) moguće interpretirati kao nerestriktivne i ako jeste, zbog čega.

U primjeru (13) uz kvantifikator svi u sastavu antecedenta nalazi se i pokazni determinator ovi. Odlika je determinatora ovi da u svojoj egzoforičnoj upotrebi

18 O kojim je autorima riječ više u Kordić 1995: 103-107. 
upućuje na nekoga ili nešto što je u blizini govornika. Ova odlika doprinosi određenosti sintagmi koje sadrže determinator ovi pa je relativne rečenice koje se pojavljuju uz antecedente koji sadrže navedeni determinator moguće interpretirati kao nerestriktivne. Također, znanje o situacijskom konteksu i mogućnost da cijeli antecedent svi ovi uspostavlja anaforičku relaciju s nečim već ranije izrečenim dopušta mogućnost da se relativna rečenica u primjeru (13) zaista interpretira kao nerestriktivna. Također, argument da determinator ovi utječe na interpretiranje rečenice kao nerestriktivne može se provjeriti ispuštanjem ovoga determinatora iz sastava antecedenta. Kada bi antecedent sadržavao samo kvantifikator svi, relativnu rečenicu nakon njega jedino bi bilo moguće interpretirati kao restriktivnu. U primjeru (14) relativna rečenica najprije se doživljava kao restriktivna budući da se njome sužava skup referenata na koji se antecedent odnosi. Dakle, ona se u ovome slučaju ponaša kao odredba. Naravno, relativnu rečenicu u ovome primjeru mogli bismo tumačiti i kao nerestriktivnu ukoliko se ona, kao dodatna obavijest, odnosi na cijelu skup referenta i ne sužava njegov značenjski opseg. Primjeri (15) i (16) u sastavu antecedenta imaju, uz kvantifikator svi, pokazni determinator oni. Tumačenju relativnih rečenica kao restriktivnih nakon ovih antecedenata doprinosi i semantika kvantifikatora svi, ali i sintaksičko-semantičke osobine pokaznoga determinatora oni. Osim što označava udaljenost i od govornika i od sagovornika (engl. distal), pokazni determinator oni, kako je u literaturi već primijećeno, ima kataforičku funkciju odabiranja. Naime, pokazni determinator oni kataforički otvara prostor atributivnoj odredbi s kojom uspostavlja referenciju.

Navedeni primjeri pokazuju kako nerestriktivna relativna rečenica kao parentetik ipak nije u potpunosti sintaksički izolirana struktura i da postoje naročite veze između domaćinske rečenice i njenih elemenata, s jedne strane, i nerestriktivne rečenice, s druge. Jedan od kriterija koji se u literaturi često navodi kao signal izoliranosti nerestriktivne relativne rečenice u odnosu na domaćinsku strukturu mogućnost je njenog izostavljanje iz linearnog ostvarenje domaćinske rečenice, bez štete po sintaksičku strukturu ili značenje. Pogledajmo sljedeće primjere:

(17) jedan stari gospodin, koji je čitavo vrijeme čitao nekakve mađarske novi$n e$, nije gledao Linu. (BAM) 
(18) Sad se tenor, koji je maločas pomenuo doktora i njegovu avanturu, ponovo podiže, ovog puta s pitanjem. (FMT)

(19) Marija je uvijek znala da dugačkim rečenicama čak i na mene, $k$ koji sam uvijek ovdje prvi čitao njena pisma, prenese svoju samoću! (FMT)

(20) Abid i sinovi, koji su sjali od nekakve zorne vatre i zvjerali okolo, priđoše. (INU)

(21) Ovo ružno oko tebe, što je izvan i u čemu si sada, gledaj kao nešto što je strano, čak i onda kada te najjače pogađa. (KNS)

Primjeri 17-21 pokazuju kako se nerestriktivne relativne rečenice zaista mogu izostaviti iz navedenih rečenica bez posljedica po strukturu. Dakle, sve navedene rečenice bile bi u potpunosti ovjerene kada bi se iz njihova sastava ukinule parentetičke strukture (up. Jedan stari gospodin nije gledao Linu, Sad se tenor ponovo podiže, ovog puta s pitanjem, Ovo ružno oko tebe gledaj kao nešto što je strano, čak $i$ onda kada te najjače pogađa). Također, relativne bi rečenice iz navedenih primjera mogle samostalno funkcionirati kao sintaksički ovjerene i semantički punoznačne strukture. Međutim, smatramo kako je ova osobina nerestriktivnih relativnih rečenica prije svega signal njihove slabije sintaksičke veze s domaćinskom strukturom (ta je veza mnogo čvršća kod restriktivnih relativnih rečenica) nego što je znak njihove sintaksičke izoliranosti.

Slabija sintaksička veza nerestriktivne relativne rečenice s domaćinskom strukturom aktuelizira pitanje vrste odnosa između nerestriktivne relativne rečenice i domaćinske strukture. Za relativnu se rečenicu u literaturi kaže kako predstavlja vrstu zavisne rečenice. Ta se zavisnost ogleda u činjenici da se relativna rečenica ponaša kao atribut prema svome antecedentu. Dakle, relativna rečenica sa svojim antecedentom čini jedan rečenični konstituent. Kordić (1995: 25) ističe kako se relativna rečenica ne uvrštava direktno u nadređenu rečenicu, već u sintagmu nadređene rečenice, te je otud njezina atributska funkcija sintagmatska, a ne rečenična.

Ipak, dok se restriktivna relativna rečenica i formalno i funkcionalno pojavljuje kao zavisna rečenica, nerestriktivna relativna rečenica pokazuje drugačiji odnos. Relativizatori koji uvode nerestriktivnu relativnu rečenicu formalna su odlika njene zavisnosti prema nadređenoj rečenici. Međutim, kada se pogleda funkcija 
koju nerestriktivna relativna rečenica vrši, postaje jasno da se ona razlikuje od restriktivne, pa su brojni autori nerestriktivnu relativnu rečenicu proglasili koordiniranom strukturom. ${ }^{19} \mathrm{Na}$ takvu interpretaciju nerestriktivne relativne rečenice utjecala je njena značenjska samostalnost i mogućnost zamjene određenom nezavisnom strukturom. Da je ta zamjena zaista moguća, pokazuju i prethodno navedeni primjeri. U svakome od njih nerestriktivnu relativnu rečenicu moguće je preoblikovati u odgovarajuću nezavisnu klauzu uvedenu veznikom $a$ :

Jedan stari gospodin, a on je čitavo vrijeme čitao nekakve mađarske novine, nije gledao Linu. (BAM)

Sad se tenor, a on je maločas pomenuo doktora i njegovu avanturu, ponovo podiže, ovog puta s pitanjem. (FMT)

Marija je uvijek znala da dugačkim rečenicama čak i na mene, $\boldsymbol{a}$ ja sam uvijek ovdje prvi čitao njena pisma, prenese svoju samoću! (FMT)

Abid i sinovi, a oni su sjali od nekakve zorne vatre i zvjerali okolo, priđoše. (INU)

Ovo ružno oko tebe, a ono je izvan i u njemu si sada, gledaj kao nešto što je strano, čak i onda kada te najjače pogađa. (KNS)

O mogućnosti zamjene nerestriktivne relativne rečenice nezavisnom klauzom govori i Palić (2015: 105) zaključujući da je takva zamjena moguća budući da je riječ o, sintaksički i semantički, vrlo sličnim kategorijama te da je upotreba relativne rečenice umjesto nezavisne klauze motivirana pragmatičkim razlozima. Mogućnost zamjene ipak ne daje potpuni odgovor na pitanje da li se između parentetičke relativne rečenice i domaćinske strukture uspostavlja odnos koordinacije ili subordinacije. Referirajući se na osobine koordinacije i subordinacije o kojima govori Palić (2015: 90-97), možemo zaključiti sljedeće:

- po mogućnosti izostavljanja iz domaćinske strukture (bez štete po sintaksičku strukturu), po uspostavljanju veze s jednim članom domaćinske strukture, a ne s cijelom strukturom (ograničen funkcionalni opseg), po nemogućnosti elidiranja istovjetnih sintaksičkih elemenata iz domaćinske strukture, po svojoj upućenosti na domaćinsku strukturu (gramatičke relacije otvorene u relativnoj rečenici zatvaraju se u domaćinskoj, nikada se ne dešava obrnuti proces), po pripadnosti relativizatora strukturi reče-

19 O kojim je autorima riječ više u Kordić 1995: 23-33. 
nice koju uvodi nerestriktivna relativna rečenica bliža je subordiniranim strukturama

- $\quad$ po svojoj značenjskoj i prozodijskoj samostalnosti nerestriktivna relativna rečenica bliža je koordiniranim strukturama.

Posebnu vrstu relativnih rečenica čine one koje uspostavlju relaciju s cijelim sadržajem domaćinske strukture, koja se ponaša kao antecedent. Takve se relativne rečenice uvijek ostvaruju kao nerestriktivne jer donose dodatnu obavijest o sadržaju iskazanom domaćinskom strukturom. Ove se rečenice uvode zamjeničkim relativizatorom. Dok je za restriktivne relativne rečenice i nerestriktivne relativne rečenice s nominalnim antecedentom karakterističan kontaktni položaj antecedenta i relativne rečenice, relativne rečenice koje uspostavljaju relaciju s cijelim sadržajem domaćinske strukture najčešće i dolaze na kraju domaćinske strukture na koju se odnose. Pogledajmo sljedeće primjere:

(22) Na brijeg su dolazili hrpimice, što odavno nije bio običaj. (INU)

(23) ...da je mali, po ugledu na Halladža, počeo pisati nerazumljive i vješto sročene stihove, što se Raziju nimalo nije dopadalo. (KDŽI)

(24) ...da je Bog, dajući čovjeku dušu, pohranio u čovjeka dio sebe, što znači da svaki čovjek u sebi, u najdubljoj dubini sebe, nosi dio Boga. (KDŽI)

(25) On će sve vrijeme gledati, slušati i udisati sebe, što znači da će sve vrijeme kažnjavati sebe, pošto sve to ne može biti ništa drugo nego teška kazna. (KDŽI)

(26) Često sam tvrđavu nazivao svojom baščom, što je znalo izazvati podsmijeh kod ljudi koji nisu u stanju shvatiti takve užitke. (KDŽI)

(27) Rob je preživio, što znači da se Husajn nije otrovao hranom, a to opet znači da je Rabija izvela nešto drugo... (KDŽI)

(28) Straža jedino može pomoći da se krivci pohvataju i kazne, što štetu neće umanjiti, ali se on i pored toga ne može naprosto okrenuti i otići. (KDŽI)

(29) A naš svijet je jedan i čitav, što znači da ga je stvorio jedan Bog, i u sebi je raznovrstan i lijepo usklađen. (KDŽI)

Nerestriktivne relativne rečenice s rečeničnim antecedentima pokazuju najveći stepen sintaksičke i semantičke samostalnosti u odnosu na domaćinsku strukturu. Naime, takve relativne rečenice donose komentar na predikaciju iz domaćin- 
ske strukture pa je njihova obavijesnost sekundarna u odnosu na tu strukturu. Upravo oslabljena sintaksička i semantička veza između nerestriktivne relativne rečenice i njene domaćinske strukture omogućava osamostaljivanje nerestriktivne relativne rečenice u zaseban iskaz ili njeno pretvaranje u nezavisnu klauzu:

Na brijeg su dolazili hrpimice, što odavno nije bio običaj. / Na brijeg su dolazili hrpimice. To odavno nije bio običaj. / Na brijeg su dolazili hrpimice, a to odavno nije bio običaj.

Ipak, odvajanjem nerestriktivne relativne rečenice u zasebnu rečenicu ili u nezavisnu klauzu stvaraju se dva jednakovrijedna iskaza koja svaki za se tvore diskurs. S druge strane, između nerestriktivne relativne rečenice i njenoga rečeničnog antecedenta uspostavljaju se unutarrečenična veza koja dovodi to toga da te dvije strukture zajedno konstruiraju diskurs. Ova se unutarrečenična veza najbolje primjećuje kod onih nerestriktivnih relativnih rečenica koje sa svojim domaćinskim strukturama ostvaruju uzročno-posljedični odnos:

(30) Selektor na njega ozbiljno računa, što njemu i te kako godi. (VN)

(31) Nakon toga sastanak je krenuo pravim tokom, što je rezultiralo i pravim rješenjem. (VN)

(32) Zatim su mu prišli stražari i gurnuli ga u jamu, što je propraćeno uzvicima negodovanja. (RHP)

(33) Porođaj će za vas biti mnogo lakši nego za starije jer su vam pelvične kosti još uvijek savitljive, što isključuje carski rez. (LZ)

U primjerima 30-31 nerestriktivnim relativnim rečenicama iskazana je posljedica radnje realizirane u domaćinskoj strukturi. Kada bi se navedene nerestriktivne relativne rečenice osamostalile $u$ posebne iskaze, $u$ prvi bi plan došla njihova informativnost, sposobnost da prenesu informaciju iskazivanjem glagolske radnje, a posljedično bi se značenje potisnulo u drugi plan. Upotrebom nerestriktivne relativne rečenice ne samo da se komentira sadržaj iskazan domaćinskom strukturom nego ukupno značenje rečenice počiva na implicitnoj semantičkoj vezi koja se ostvaruje između parentetika i domaćinske strukture. Takav tip nerestriktivne relativne rečenice u literaturi se naziva i kontinuativnom ${ }^{20}$ nerestriktivnom relativnom rečenicom. Ovdje se kontinuativnost posmatra kao

20 Više u Loock 2010: 96-103. 
semantička i pragmatička osobina, a to znači da se ovom vrstom nerestriktivne relativne rečenice ne iznose pozadinske informacije (engl. background informations) već informacije koje pripadaju prvome planu (engl. foreground informations), jednako kao i informacije koje donosi domaćinska struktura. Povezane u jednu složenu jedinicu, domaćinska struktura i nerestriktivna relativna rečenica daju informacije o dvama semantički povezanim sadržajima koji se na razini diskursa ostvaruju kao sadržaj koji prethodi i onaj koji slijedi (koji mu je sukcesivan), a među njima se uspostavlja naročit kauzativni odnos.

\section{Zaključak}

Parentetičke strukture predstavljaju vrlo složenu i zanimljivu sintaksičku, semantičku i pragmatičku kategoriju. Posmatrani kroz suodnos hijerarhijske organizacije i linearne ostvarenosti, parentetici se u svjetskoj lingvističkoj literaturi proglašavaju ili rečeničnim disjunktima ili adjunktima. I jedna i druga karakterizacija parentetika zasniva se na postojanju sintaksičke veze između parentetika i domaćinske strukture. Posebnu vrstu parentetičkih struktura čine klauzalni parentetici, a u njima značajno mjesto pripada nerestriktivnoj relativnoj rečeni$c i$. Nerestriktivna relativna rečenica tipičan je primjer parentetika budući da se od svoje domaćinske stukture uvijek odvaja zarezom (ili nekim drugim pravopisnim znakom) signalizirajući time svoju intonacijsku, prozodijsku, sintaksičku, semantičku i pragmatičku zasebnost. Provedeno istraživanje obuhvatilo je dva tipa nerestriktivnih relativnih rečenica - one kojima je antecedent nominalna fraza iz domaćinske strukture i one koje za antecedent imaju cijeli sadržaj domaćinske strukture. Analiza je rezultirala sljedećim zaključcima:

- nerestriktivne relativne rečenice ne mogu se u potpunosti proglasiti sintaksički izoliranim jedinicama

- moguće je govoriti o čvršćoj ili slabijoj sintaksičkoj vezi između nerestriktivne relativne rečenice i njene domaćinske strukture

- nerestriktivna relativna rečenica pozicijski je ograničena (dolazi u kontaktu)

- nerestriktivna relativna rečenica stoji u odnosu subordinacije prema domaćinskoj strukturi, ali zadržava i određene osobine koordiniranih struktura

- najslabiju vezu s domaćinskom strukturom pokazuju nerestriktivne relativ- 
ne rečenice s rečeničnim antecedentom

- pragmatički posmatrane, nerestriktivne relativne rečenice donose dodatnu obavijest o nekome elementu domaćinske strukture ili predstavljaju komentar sadržaja domaćinske strukture

- kontinuativne nerestriktivne relativne rečenice nose obavijest koja pripada fokusu i s domaćinskom strukturom uspostavljaju kauzativni odnos.

\section{Izvori:}

BNLJ = Bazdulj-Hubijar, Nura. 1994. Ljubav je sihirbaz, babo. Svjetlost. Sarajevo.

BAM = Bjelevec, Abdurezak Hifzi. 1996. Minka. Preporod. Sarajevo.

FMT = Fehimović, Mirza. 1996. To jest žizni njet. Bosanska knjiga. Sarajevo.

FSP $=$ Fetahagić, Sead. 1996. Poljubi pa ostavi. Bosanska knjiga. Sarajevo.

HIP = Horozofić, Irfan. 1994. Prognani grad. Aktant d.o.o. Zagreb.

INU = Ibrišimović, Nedžad. 1996. Ugursuz. Preporod. Sarajevo.

KDŽI = Karahasan, Dževad. 1994. Istočni diwan. Bosanska biblioteka. Klagenfurt Celovec.

KHS = Krstić, Nikola. 1996. S druge strane rijeke. Lettre international. Sarajevo.

RHP = Ramadan, Hajrudin. 1996. Priče od kiše. Bosanska knjiga. Sarajevo.

$\mathrm{VN}=$ Večernje novine. 1996.

$\mathrm{LZ}=$ Žena 21 - List za ženu i porodicu. 1997. Humanitarno udruženje građana Žena 21 .

\section{Literatura:}

Alexiadou, Artemis i dr. 2000. The syntax of relative clauses. John Benjamins Publishing Company. Amsterdam - Philadelphia.

Arnold, Doug. 2004. Non-Restrictive Relative Clauses in Construction-Based HPSG. Proceedings of the 11th International Conference on Head-Driven Phrase Structure Grammar. Ur. Muller, Stefan. Center for Computational Linguistics - Katholieke Universiteit Leuven. Stanford.

Blakemore, Diane. 2006. Division of labour: the analysis of parentheticals. Lingua 116. 1670-1687.

Browne, WAYLES. 1986. Relative clauses in Serbo-Croatian in comparison with English. Faculty of Philosophy - Institute of Linguistics. Zagreb. 
Burton-Roberts, Noel. 2006. Parentheticals. Encyclopedia of Language and Linguistics. $2^{\text {nd }}$ edition, Vol. 9. Ur. Brown, E. K. Elsevier. Amsterdam.

De Vries, Mark. 2007. Invisible constituents. Parentheticals. Ur. Dehe, Nicole; Kavalova, Yordanka. John Benjamins Publishing Company. Amsterdam - Philadelphia.

Dehe, Nicole. 2009. Clausal parentheticals, intonational phrasing, and prosodic theory. Journal of Linguistics 45/3. 569-615.

Dehe, Nicole; Kavalova, Yordanka. 2007. Parentheticals - An introduction. Parentheticals. Ur. Dehe, Nicole; Kavalova, Yordanka. John Benjamins Publishing Company. Amsterdam - Philadelphia.

Del Gobbo, Francesca. 2007. On the syntax and semantics of appositive relative clauses. Parentheticals. Ur. Dehe, Nicole; Kavalova, Yordanka. John Benjamins Publishing Company. Amsterdam - Philadelphia.

Espinal, Teresa M. 1991. The representation of disjunct constituents. Language 67. $726-762$.

Grenoble, Lenore. 2004. Parentheticals in Russian, Journal of Pragmatics 36. 19531974.

GRIfFiths, JAMES. 2013. Parenthetical verb constructions, fragment answers, and constituent modification. Natural Language and Linguistic Theory 33/1. 191-229.

Jackendoff, Ray. 1977. X-bar Syntax: a Study of Phrase Structure. MIT Press. Cambridge.

Kaltenbock, Gunther. 2007. Spoken parenthetical clause in English. Parentheticals. Ur. Dehe, Nicole; Kavalova, Yordanka. John Benjamins Publishing Company. Amsterdam - Philadelphia.

Kaltenbock, Gunther; Heine, Bernd; Kuteva, Tania. 2011. On thetical grammar. Studies in language 35/4. 852-897.

Keenan, Edward; Comrie, Bernard. 1977. Noun phrase accessibility and universal grammar. Linguistic Inquiry 8. 63-99.

Kordić, SnJežAnA. 1995. Relativna rečenica. Matica hrvatska. Zagreb.

Loock, Rudy. 2010. Appositive relative clauses in English: discourse functions and competing structures. John Benjamins Publishing Company. Amsterdam - Philadelphia.

Minaljević, Milan. 2013. Parenteza s glagolima govorenja u hrvatskom jeziku. Rasprave Instituta za hrvatski jezik i jezikoslovlje 39/2. 527-544.

McCawley, James. 1982. Parentheticals and discontinuous constituent structure. Linguistic Inquiry 13/1. 91-106.

Palić, Ismail. 2015. Rasprave iz sintakse i semantike. Bosansko filološko društvo. Sarajevo.

PALIĆ, Ismail. 2019. Gramatika, semantika i pragmatika rečenice. Institut za jezik Uni- 
verziteta u Sarajevu. Sarajevo.

PotTs, Christopher. 2005. The Logic of Conventional Implicatures. Oxford University Press. Oxford.

Pranjković, Ivo. 2001. Druga hrvatska skladnja. Hrvatska sveučilišna naklada. Zagreb.

Proceedings of the $11^{\text {th }}$ International Conference on Head-Driven Phrase Structure Grammar. 2007. Ur. Muller, Stefan. CA: CSLI Publications. Stanford.

Reinhart, Tanya. 1983. Anaphora and semantic interpretation. Croom Helm. London. Silić, Josip; Pranjoović, Ivo. 2005. Gramatika hrvatskoga jezika-Za gimnazije i visoka učilišta. Školska knjiga. Zagreb.

Sperber, Dan; Deirdre Wilson. 1986. Relevance: Communication and Cognition. Blackwell Publishers Ltd. Oxford.

TABAKOWSKa, ElzBieta. 1985. Restrictiveness as a semantic and pragmatic property of English and Polish relative clauses. Uniw. Jagiellonski. Krakow.

Urmson, JAmes. 1952. Parenthetical verbs, Mind 61/244. 480-496.

Quirk, Randolph i dr. 1985. A Coprehensive Grammar of the English Language. Longman. Harlow.

\section{Non-restrictive Relative Sentence as a Parenthetical}

\section{Abstract}

In this paper, we will seek to describe inserted non-restrictive relative sentences as typical parenthetical structures. The description will include their syntactic and semantic interpretation, as well as indications about their pragmatic role, and will be based on an analysis of examples found in a corpus of texts belonging to different styles of Bosnian language. The paper is divided into three parts. In the first part, we will define parentheticals and give an overview of the approaches taken so far in analyzing this phenomenon. In the second part of the paper, we will focus on defining and analyzing the inserted non-restrictive relative sentences, and in the third part, we will highlight the most significant observations.

Ključne riječi: sintaksa, semantika, pragmatika, parentetici, nerestriktivna relativna rečenica Keywords: syntax, semantics, pragmatics, parentheticals, non-restrictive relative sentence 